Tropical Journal of Pharmaceutical Research, June 2009; 8 (3): 201-207

(C) Pharmacotherapy Group,

Faculty of Pharmacy, University of Benin

Benin City, 300001 Nigeria.

All rights reserved.

Research Article

Available online at http://www.tjpr.org

\title{
Antidiarrheal Activity of the Ethyl Acetate Extract of Morinda morindoides in Rats
}

\author{
S Meite ${ }^{1 *}$, J D N'guessan ${ }^{1}$, C Bahi ${ }^{1}$, H F Yapi ${ }^{1}$, A J Djaman ${ }^{1,2}$ \\ and $F$ Guede Guina ${ }^{1}$
}

${ }^{1}$ Biochemical Pharmacodynamy Laboratory, Biosciences Department, Cocody University PO Box 582, Abidjan 22,

${ }^{2}$ Biochemical Laboratory of Pasteur Institut of Côte d'Ivoire, PO Box 490, Abidjan 01, Côte d'Ivoire.

\begin{abstract}
Purpose: The objective of the study was to investigate the ethyl acetate extract of Morinda morindoides (Baker) Milne-Redh (Rubiaceae) (MM-EA) properties against experimental diarrheoa induced by castor oil in albino Wistar rats.

Methods: The ethyl acetate extract of Morinda morindoides (250, 500, and $1000 \mathrm{mg} / \mathrm{kg}$ body weight) was administered orally to three groups of rats (five animals per group) in order to evaluate the activity of the extract against castor oil-induced diarrhea model in rat. Two other groups received normal saline $(5 \mathrm{mg} / \mathrm{kg})$ and loperamide $(5 \mathrm{mg} / \mathrm{kg})$ as positive control. The effect of the extract on intestinal transit and castor oil-induced intestinal fluid accumulation (enteropooling) was assessed.

Results: At oral doses of 250, 500, and $1000 \mathrm{mg} / \mathrm{kg}$ body weight, the plant extract showed pronounced and dose-dependent antidiarrheal activity. The protective role of the extract at $1000 \mathrm{mg} / \mathrm{kg}$ was comparable to that of the reference drug, loperamide $(5 \mathrm{mg} / \mathrm{kg})$. The extract $(1000 \mathrm{mg} / \mathrm{kg})$ produced a decrease in intestinal transit comparable to atropine $(5 \mathrm{mg} / \mathrm{kg})$, and significantly $(p<0.01)$ inhibited castor oil-induced enteropooling. No mortality and visible signs of general weakness were observed in the rats following the extract administration of up to a dose of $6000 \mathrm{mg} / \mathrm{kg}$.
\end{abstract}

Conclusion: The results showed that the extract of $M$. morindoides has a significant antidiarrheal activity which supports its use in traditional herbal medicine practice.

Keywords: Antidiarrheal activity, Castor oil, Morinda morindoides, Intestinal transit, enteropooling 


\section{INTRODUCTION}

Diarrheal diseases are a major problem in Third World countries and are responsible for the death of millions of people each year ${ }^{1}$. Diarrheoa is an alteration in normal bowel movement and is characterized by an increase in the water content, volume, or frequency of stools ${ }^{2}$. Plants have long been a very important source of new drugs. Many plant species have been screened for substances with therapeutic activity. Medicinal plants are a promising source of antidiarrheal drugs $^{3}$. For this reason, international organizations including the World Health Organization (WHO) have encouraged studies pertaining to the treatment and prevention of diarrheal diseases using traditional medical practices $^{4,5,6}$. Morinda morindoides (Baker) Milne-Redh (Rubiaceae) is found in the borders of tropical forests. In the Democratic Republic of Congo, M. morindoides has long been used in villages and towns in the treatment of some parasitic diseases, and the leaf extracts of the plant have been shown to possess antiprotozoal activity particularly against Entamoeba histolytica and rheumatic pain $^{7,8}$. The decoction of the leaves is used for the treatment of malaria, intestinal worms, and amoebiasis ${ }^{9,10}$. Recently Zirihi et al ${ }^{11}$ have shown that the ethanol extract of $M$. morindoides exhibited good in vitro antimalarial activity against chloroquineresistant FcB1/Colombia strain of Plasmodium falciparum.

Ten flavonoids which were identified as quercetin, quercetin-7, 4-dimethylether, quercetin-3-O-rutinoside, quercetin-3-Orhamnoside, kaempferol-3-O-rhamnoside, kaempferol-3-O-rutinoside, kaempferol-7-Orhamnosylsophoroside, chrysoeriol-7-Oneohesperidoside, apigenin-7-O-glucoside, luteolin-7-O-glucoside ${ }^{12-14}$ have been isolated from the butanol and ethyl acetate fractions of the plant leaves. In addition, a total of eight iridoid glycosides, among which are gaertneroside and gaertneric acid, methoxygaertneroside and epoxygaertneroside, were also isolated from the same fractions by Cimanga et $a \hat{\beta}$.

M. morindoides is well known in the traditional medical practice of the west central part of Ivory Coast. It is commonly called Zêlékelé in the local language of 'Bété' and is used as an antifungal agent. The leaves of the plant are used in traditional medicine to treat diarrheoa. The present work was undertaken to investigate the potential in vivo antidiarrheal effect of the ethyl acetate extract of $M$. morindoides in various experimental models of diarrhoea in rats.

\section{MATERIALS AND METHODS}

\section{Plant material}

The leaves of Morinda morindoides (Rubiaceae) were collected from Daloa (central west region of Ivory Coast) in June 2006. The plant was identified and authenticated by $\operatorname{Pr}$ AKE ASSI, of the Department of Botany, University of Cocody. A voucher specimen (no17710) of the plant was deposited in the herbarium of the National Floristique Center of the University of Cocody-Abidjan.

\section{Preparation of ethyl acetate extract}

The leaves of $M$. morindoides were cleaned of extraneous matter, air-dried at room temperature for 7 days and ground into a fine powder. The powder was mixed with distilled water ( $80 \mathrm{~g}$ of powder in $2 \mathrm{~L}$ of distilled water) for $24 \mathrm{~h}$ with constant stirring at $80^{\circ} \mathrm{C}$. The extract was filtered twice through cotton wool, then through Whatman filter paper (No. 1). The filtrate was evaporated to dryness using a rotary evaporator (Buchi). Twenty five grams $(25 \mathrm{~g})$ of the dry aqueous extract was dissolved in $500 \mathrm{ml}$ of ethanol and water (consisting of $350 \mathrm{ml}$ of ethanol $96 \%$ and 150 $\mathrm{ml}$ of distilled water) and after thorough mixing, the supernatant was evaporated using a rotary evaporator. Following the method of Guede-Guina et $a l^{15}, 25 \mathrm{~g}$ of the dried extract was dispersed in $500 \mathrm{ml}$ of a 
solution (made up of $250 \mathrm{ml}$ of ethyl acetate and $250 \mathrm{ml}$ of distilled water), and mixed for $24 \mathrm{~h}$ with constant stirring. From the two phases formed, the supernatant was evaporated using a rotary evaporator, and the resulting dry powder was taken as the ethyl acetate extract.

\section{Animal}

Albino Wistar rats (weighing $150-200 \mathrm{~g}$ ) of both sexes, were housed in standard metal cages. They were provided with food and water ad libitum, and allowed a one-week acclimatization period prior to the study. The equipment, handling and sacrificing of the animals were in accordance with the European Council legislation 87/609/EEC for the protection of experimental animals ${ }^{16}$.

\section{Drug and chemicals}

Atropine sulphate and loperamide (Sigma Chemical Co, St Louis, Mo, USA), castor oil (Qualikems Fine Chemicals Pvt. Ltd, New Delhi, India), normal saline ( $\mathrm{NaCl} 0.9 \%)$ and charcoal meal (10\% activated charcoal in 100 $\mathrm{ml}$ of $5 \%$ aqueous gum acacia) were used.

\section{Preliminary acute toxicity test}

The extract of $M$. morindoides was administered orally in doses of $125,250,500$, $1000,2000,4000$ and $6000 \mathrm{mg} / \mathrm{kg}$ body weight to animal groups (one dose per group). Simultaneously, the control animals received normal saline $(5 \mathrm{ml} / \mathrm{kg})$. The general signs and symptoms of toxicity, intake of food and water and mortality were recorded for a period of $48 \mathrm{~h}$ and then for a period of 14 days.

\section{Castor oil-induced diarrhea in rats}

Twenty five (25) rats were fasted for $18 \mathrm{~h}$ and divided into five groups of five animals each. The plant extract $(250,500$, and $1000 \mathrm{mg} / \mathrm{kg}$ body weight) were administered orally to groups 1, 2 and 3, respectively. The fourth group received normal saline $(5 \mathrm{ml} / \mathrm{kg}$ body weight) and served as control, while the fifth group received the standard drug, loperamide (5 mg/kg body weight). One hour later, all the animals received $2 \mathrm{ml} / \mathrm{rat}$ of castor oil orally by gavage. The animals were kept in separate metabolic cages with a transparent plastic container beneath the cage to collect faeces ${ }^{17}$. The severity of diarrheoa was assessed each hour for $6 \mathrm{~h}$. The total number of faeces (both diarrheal and non-diarrheal) expelled were compared with the control group. The total score of diarrheal faeces for the control group was considered as $100 \%$. The results were expressed as a percentage of inhibition of diarrheoa.

\section{Gastrointestinal motility test}

The rats were divided into five groups of five animals each and fasted for $18 \mathrm{~h}$ but water was freely provided. The first group (control group) received orally normal saline $(5 \mathrm{ml} / \mathrm{kg}$ body weight), while the second, third and fourth groups were given orally the plant extract in doses of 250,500 , and $1000 \mathrm{mg} / \mathrm{kg}$ body weight, respectively. The fifth group received orally the standard drug, atropine sulphate ( $5 \mathrm{mg} / \mathrm{kg}$ body weight). Thirty (30) min later, each animal was given $1 \mathrm{ml} /$ rat of charcoal meal (10\% activated charcoal in 5\% gum acacia) via the oral route. All animals were sacrificed $30 \mathrm{~min}$ thereafter, and the distance covered by the charcoal meal in the intestine, from the pylorus to the caecum was measured and expressed as percentage of distance moved $^{18}$.

\section{Castor oil-induced enteropooling}

Intraluminal fluid accumulation was determined by the method of Robert et $\mathrm{al}^{19}$. Rats were divided into five groups of five animals each, one hour before oral administration of castor oil (2 $\mathrm{ml} / \mathrm{rat})$. Group 1 received normal saline orally $(5 \mathrm{ml} / \mathrm{kg}$ body weight), and served as the control. Group 2 animals received loperamide $(5 \mathrm{mg} / \mathrm{kg}$, oral) while groups 3,4 , and 5 received, by oral intubation, the extract of $M$. morindoides at doses of 250, 500 and $1000 \mathrm{mg} / \mathrm{kg}$ body 
weight, respectively. Two hours later, the rats were sacrificed and the small intestine from the pylorus to the caecum was isolated. The intestinal contents were collected by milking into a graduated tube and their volume measured.

\section{Statistical analysis}

Data were analyzed by one-way ANOVA followed by Dennett's t-test using Instat ${ }^{\circledR}$ (Graph Pad software, U.S.A). At 95\% confidence interval $p<0.05$ was considered statistically significant.

\section{RESULTS}

\section{Preliminary acute toxicity test}

It was observed that oral administration of the extract of $M$. morindoides to the rat up to $6000 \mathrm{mg} / \mathrm{kg}$ neither showed mortality nor any apparent signs of weakness in the animals.

\section{Effect of M. morindoides extract on castor oil-induced diarrheoa}

In the castor oil-induced diarrheoa experiment, the extract of $M$. morindoides produced a marked antidiarrheal effect in the rats, as shown in Table 1. At doses of 250, 500 , and $1000 \mathrm{mg} / \mathrm{kg}$, the extract significantly decreased $(p<0.01)$ the total number of wet faeces produced upon administration of castor oil $(12.20 \pm 1.06$ at $250 \mathrm{mg} / \mathrm{kg}, 7.00 \pm$ 0.94 at $500 \mathrm{mg} / \mathrm{kg}$ and $6.20 \pm 0.58$ at 1000 $\mathrm{mg} / \mathrm{kg}$ ) compared to the control group (18.6 \pm $0.74)$. The effect of the highest dose of the extract was similar to that of the standard drug, loperamide (5 mg/kg).

\section{Effect of $M$. morindoides extract on intestinal transit of charcoal meal}

The extract of $M$. morindoides decreased propulsion of charcoal meal in the rat gastrointestinal tract at oral doses of 250 $1000 \mathrm{mg} / \mathrm{kg}$, compared with the control group that receiving normal saline $(5 \mathrm{mg} / \mathrm{kg})$. A similar reduction in the gastrointestinal transit of charcoal meal in rat was achieved with atropine sulphate $(5 \mathrm{mg} / \mathrm{kg})$. The results are shown in Table 2.

\section{Effect of extract of $M$. morindoides on castor oil-induced enteropooling}

Morinda morindoides extract significantly $(\mathrm{P}<$ 0.01) inhibited castor oil-induced enteropooling in rats at oral doses of 500 and $1000 \mathrm{mg} / \mathrm{kg}$ (Table 3). The intestinal fluid in control animals was $3.44 \pm 0.36 \mathrm{ml}$. The inhibition of intestinal accumulation was $24.41 \%(P<0.01), 52.32 \%(P<0.01)$ and $61.04 \%(P<0.01)$ at doses of 250,500 , and $1000 \mathrm{mg} / \mathrm{kg}$ of the extract, respectively. The standard drug, loperamide (5 mg/kg), also significantly inhibited $(P<0.01)$ intestinal fluid accumulation (59.30\%).

\section{DISCUSSION}

In the traditional medicine system, Morinda morindoides is used in the management of diarrheoa by traditional medicine practitioners in Ivory Coast. The present study sought to assess the antidiarrheal activity of the plant.

Our results showed that the extract inhibited significantly $(p<0.01)$ castor oil-induced diarrheoa in rats. Several mechanisms had been previously proposed to explain the diarrheal effect of castor oil. These include inhibition of intestinal $\mathrm{Na}^{+} \mathrm{K}^{+}$ATPase activity, thus reducing normal fluid absorption ${ }^{20}$, activation of adenylate cyclase or mucosal cAMP-mediated active secretion ${ }^{21}$, stimulation of prostaglandin formation ${ }^{22}$, and platelet activating factor ${ }^{23}$. Most recently nitric oxide has been claimed to contribute to the diarrheal effect of castor oil ${ }^{24}$. However, it is well documented that castor oil produces diarrhoea due to its most active component ricinoleic acid through a hypersecretory response ${ }^{25,26}$. Therefore it can be assumed that the antidiarrheal action of the extract was mediated by an antisecretory mechanism. This was also evident from the inhibition of castor oil-induced fluid accumulation by the extract. The results were comparable to those of the standard drug, loperamide. 
Table 1: Effect of the extract of $M$. morindoides (MM-EA) on castor-oil induced diarrheoa in rat. Values are expressed as mean \pm S.E.M $(n=5)$. ${ }^{* \star} P<0.01$, when compared to the control.

\begin{tabular}{lccc}
\hline Treatment & $\begin{array}{c}\text { Total number of } \\
\text { faeces }\end{array}$ & $\begin{array}{c}\text { Number of } \\
\text { diarrhoea faeces }\end{array}$ & $\begin{array}{c}\text { Inhibition of } \\
\text { diarrhoea }(\%)\end{array}$ \\
\hline Normal saline $(5 \mathrm{mg} / \mathrm{kg})+$ Castor oil $(2 \mathrm{ml})$ & $22.80 \pm 0.86$ & $18.6 \pm 0.74$ & \\
Loperamide $(5 \mathrm{mg} / \mathrm{kg})+$ Castor oil $(2 \mathrm{ml})$ & $9.80 \pm 1.65^{\star *}$ & $5.20 \pm 1.15^{* *}$ & 72.04 \\
MM-EA $(250 \mathrm{mg} / \mathrm{kg})+$ Castor oil $(2 \mathrm{ml})$ & $19.80 \pm 0.73$ & $12.20 \pm 1.06^{* *}$ & 34.40 \\
MM-EA $(500 \mathrm{mg} / \mathrm{kg})+$ Castor oil $(2 \mathrm{ml})$ & $16.40 \pm 1.12^{* *}$ & $7.00 \pm 0.94^{\star *}$ & 62.36 \\
MM-EA $(1000 \mathrm{mg} / \mathrm{kg})+$ Castor oil $(2 \mathrm{ml})$ & $15.60 \pm 1.80^{* *}$ & $6.20 \pm 0.58^{* *}$ & 67.00 \\
\hline
\end{tabular}

Values are expressed as mean \pm S.E.M $(n=5){ }^{* *} p<0.01$, when compared to the control

Table 2: Effect of extract of M. morindoides (MM-EA) on the intestinal transit of charcoal meal in rat

\begin{tabular}{lcc}
\hline Treatment & Distance travelled by charcoal $(\%)$ & Inhibition (\%) \\
\hline Normal saline $(5 \mathrm{mg} / \mathrm{kg})$ & $73.95 \pm 3.55$ & \\
Atropine $(5 \mathrm{mg} / \mathrm{kg})$ & $30.85 \pm 1.69^{* *}$ & 58.28 \\
MM-EA $(250 \mathrm{mg} / \mathrm{kg})$ & $61.81 \pm 3.45^{\star}$ & 16.41 \\
MM-EA $(500 \mathrm{mg} / \mathrm{kg})$ & $48.00 \pm 2.59^{* *}$ & 35.09 \\
MM-EA $(1000 \mathrm{mg} / \mathrm{kg})$ & $35.62 \pm 3.63^{* *}$ & 51.83 \\
\hline
\end{tabular}

Values are expressed as mean \pm S.E.M $(n=5){ }^{*} P<0.05,{ }^{* *} p<0.01$, when compared to the control

Table 3: Effect of extract of M .morindoides (MM-EA) on castor-oil induced enteropooling in rat

\begin{tabular}{lcc}
\hline Treatment & $\begin{array}{c}\text { Volume of intestinal } \\
\text { fluid }(\mathrm{ml})\end{array}$ & Inhibition (\%) \\
\hline Normal saline $(5 \mathrm{mg} / \mathrm{kg})+$ Castor oil $(2 \mathrm{ml})$ & $3.44 \pm 0.36$ & \\
Loperamide $(5 \mathrm{mg} / \mathrm{kg})+$ Castor oil $(2 \mathrm{ml})$ & $1.40 \pm 0.24^{\star *}$ & 59.30 \\
MM-EA $(250 \mathrm{mg} / \mathrm{kg})+$ Castor oil $(2 \mathrm{ml})$ & $2.60 \pm 0.55$ & 24.41 \\
MM-EA $(500 \mathrm{mg} / \mathrm{kg})+$ Castor oil $(2 \mathrm{ml})$ & $1.64 \pm 0.20^{\star *}$ & 52.32 \\
MM-EA $(1000 \mathrm{mg} / \mathrm{kg})+$ Castor oil $(2 \mathrm{ml})$ & $1.34 \pm 0.09^{\star *}$ & 61.04 \\
\hline
\end{tabular}

Values are expressed as mean \pm S.E.M $(n=5) .{ }^{* *} P<0.01$, when compared to the control

Furthermore, the extract significantly reduced intestinal transit as evidenced by the decrease in the distance traveled by charcoal meal. These results also show that the extract suppressed the propulsion of charcoal meal thereby increasing the absorption of water and electrolytes. Antidiarrheal properties of medicinal plants were found to be due to tannins, flavonoids, alkaloids, saponins, reducing sugar, sterols and/or terpenes ${ }^{27,28}$. The antidiarrheal activity of flavonoids has been ascribed to their ability to inhibit intestinal motility and hydro-electrolytic secretions $^{29,30}$ which are altered in this intestinal condition. In vitro and in vivo experiments have shown that flavonoids are 
able to inhibit the intestinal secretory response induced by prostaglandins $\mathrm{E}_{2}{ }^{31}$. In addition, flavonoids present antioxidant properties ${ }^{32}$ which are presumed to be responsible for the inhibitory effects exerted upon several enzymes including those involved in the arachidonic acid metabolism ${ }^{33}$. These constituents may be responsible for the antidiarrheal activity of the ethyl acetate extract of $M$. morindoides.

\section{CONCLUSION}

The results of this investigation revealed that M. morindoides contains pharmacologically active substances with antidiarrheal properties. These attributes may provide the rationale for the use of Morinda morindoides in diarrheoa management by traditional healers. Further research is needed to fractionate the ethyl acetate extract and isolate the molecule(s) responsible for the antidiarrheal activity observed.

\section{ACKNOWLEDGEMENT}

The authors wish to thank Pr. Aké-Assi of the Department of Botany, University of CocodyAbidjan, for the botanical identification and collection of the plant

\section{REFERENCES}

1.Shoba FG, Thomas M. Study of antidiarrheal activity of four medicinal plants in castor oil-induced diarrhea. J Ethnopharmacol, 2001; 76: 73-76.

2. Guerrant RL, Van Gilder T, Steiner TS, Theilman MN, Slutsker L, Tauxe RV. Practice guidelines for the management of infectious diarrhea. Clin Infect Dis, 2001; 32: 331-35

3. Maikere-Faniyo R, Van Puyvelde L, Mutwewingabo A, Habiyaremye FX. Study of Rwandese medicinal plants used in the treatment of diarrhea. J Ethonopharmacol, 1989; 26: 101-109.

4. Syder JD, Merson MH. The magnitude of the global problems of acute diarrheal disease: $A$ review of active surveillance data. Bull WHO, 1982; 60 : 605-613.

5. Lutterodt GD. Inhibition of gastrointestinal release of acetylcholine by quercetin as a possible mode of action of Psidium guajava leaf extracts in the treatment of acute diarrhea disease. $J$ Ethnopharmacol, 1989; 25: 235-247.
6. Park K. Park's Text book of Preventive and Social Medicine. Jabalpur,India,M/S Banarsidas Bharat Publishers, Jabalpur, 2000, pp.172175.

7. Cimanga K, Kambu K, Tona L, Hermans N, Apers S, Totté J, Pieters L, Vlietinck AJ. Cytotoxicity and in vitro susceptibility of Entamoeba histolytica to Morinda morindoides leaf extracts and its isolated constituents. J Ethnopharmacol, 2006; 107: 83-90.

8.Cimanga K, Hermans $N$, Apers S, Van Miert S, Van den Heuvel H, Claeys M, Pieters L, Vlietinck AJ. Complement-inhibiting iridoids from Morinda morindoides. J Nat Prod, 2003; 66: 97-102.

9. Kambu K, Tona L, Luki N, Cimanga K, Uvoya A. Antibacterial activity of extracts from plants used in preparations as antidiarrheal at Kinshasa, Zaire. Ann Pharm Fr, 1990; 48(5): 255-263.

10.Tona L, Ngimbi NP, Tsakala M, Mesia K, Cimanga RK, Apers S, De Bruyne T, Totte J, Pieters L, Vlietinck AJ. Biological sceening of traditional preparations from some medicinal plants used as antidiarrheal in Kinshasa, Congo. Phytomedicine, 1999; 6(1): 59-66.

11. Zirihi GN, Mambu L, Guédé-Guédé $F$, Bodo $B$, Grellier P. In vitro antiplasmodial activity and cytotoxicity of 33 West African plants used for the treatment of malaria. J Ethnopharmacol, 2005; 98: 281-285.

12. Cimanga K, De Bruyne T, Lasure A, Li Q, Pieters L, Claeys $M$, Vanden Berghe $D$, Kambu K, Tona $L$, Vlietinck AJ. Flavonoid o-glycosides from the leaves of Morinda morindoides. Phytochem, 1995; 38: 1301-1303.

13. Cimanga K, De Bruyne T, Van Poel B, Ma Y, Claeys $M$, Pieters L, Bakana $P$ Kambu K, Tona L, Vanden Berghe $D$, Vlietinck AJ. Complementmodulating properties of a kaempferol 7-0rhamnosyl-sophoroside from the leaves of Morinda morindoides. Planta Med, 1997; 63. 220-223

14. Cimanga $K$, De Bruyne $T, H u J P$, Cos $P$, Apers $S$, Pieters L, Tona L Kambu K, Vanden Berghe $D$, Vlietinck AJ. Constituents from Morinda morindoides leaves as inhibitors of xanthine oxidase and scavengers of superoxide anions Pharm Pharmacol Com, 1999; 5: 419-424.

15. Guede-guina $F$, Vangah-Manda M, Harouna D, Bahi C. Potencies of misca, a plant source concentrate against fungi. J Ethnopharmacol, 1993; 14: 45-53.

16. Mitjans M, Garcia L, Marrero E, Vinardell MP. Study of ligmed- $A$, an antidiarrheal drug based on liguin, on rat small intestine enzyme activity and morphometry. J Vet Pharmacol Ther, 2008; 24 . 349-351.

17. Awouters F, Niemegeers CJE, Lenaerts F.M, Janseen $P A . J$. Delay of castor oil diarrhea in rats; a new way to evaluate inhibitors of prostaglandin biosynthesis. J Pharmacol, 1978; 30: 41-45.

18. Pazhani GP, Subramanian N, Arunchalam G, Hemalatha S, Ravichandran V. Antidiarrheal 
potential of Elephantopus scaber Linn leaf extract. Ind drugs, 2001; 38 (5): 269-271.

19. Robert A, Nezamis JE, Lancaster C, Hanchar AJ, Klepper MS .Enteropooling assay, a test for diarrhea produced by prostaglandins, Prostagladins, $1976 ; 11: 809-8028$.

20. Gaginella TS, Bass P. Laxatives: an update on mechanism of action. Life Sci, 1978; 23: 10011010.

21. Capasso F, Mascolo N, Izzo A.A, Gaginella TS. Dissociation of castor oil-induced diarrhea and intestinal mucosal injury in rat: effect of NGnitro-L-arginine methyl ester. Br J Pharmacol, 1994; 113: 1127-1130.

22. Galvez J, Zavzuelo A, Crespo, ME, Lorente MD, Ocete MA, Jimenez J. Anti-diarrhoeic activity of Euphorbia hirta extract and isolation of an active flavonoid constituent. Planta Med, 1993; 59: 333-336.

23. Pinto A, Autore G, Mascolo N, Sorrentino R, Biondi A, Izzo $A A$, Capasso $F$. Time course of PAF formation by gastrointestinal tissue in rats after castor oil challenge. J Pharm Pharmacol, 1992; 44: 224-226.

24. Mascolo N, Izzo AA, Gaginella TS, Capasso F. Relationship between nitric oxide and plateletactivating factor in castor oil-induced mucosal injury in the rat duodenum. Naunyn Schmiedebergs Arch Pharmacol, 1996; 353: 680-684.

25. Ammon HV,Thomas PJ, Phillips SF. Effect of the oleic acid and ricinoleic acid net jejunal water and electrolyte movement. J Clin Invest, 1974; 53: 374-379.

26. Gaginella TS, Stewart JJ, Olsen WA, Bass P. Action of ricinoleic acid and structurally related fatty acid on the gastrointestinal tract. II. Effect on water and electrolyte absorption in vitro. J Pharmacol Exp Ther, 1975; 195: 355-356.

27. Longanga Otshudi $A$, Vercruysse $A$, Foriers $A$. Contribution to the ethnobotanical, phytochemical and pharmacological studies of traditionally used medicinal plant in the treatment of dysentery and diarrhea in Lomela area, Democratic Republic of Congo (DRC). J Ethnopharmacol, 2000; 71(3): 411-423.

28. Venkatesan N, Thiyagarajan V, Narayanan S, Arul A, Raja S, Kumar SGV, Rajarajan $T$, Perianayagam JB. Antidiarrheal potential of Asparagus racemous wild root extracts in laboratoire animals. J Pharm Pharmaceut Sci, 2005; 8(1): 39-45.

29. Di Carlo G, Autore G, Izzo AA, Maibline P, Mascolo $N$, Viola $P$, Diurno MV, Capasso F. Inhibition of intestinal motility and secretion by flavonoids in mice and rats: Structure activity relationships. $J$ Pharmacol, 1993; 45: 1054-1059.

30. Rao VSN, Santos FA, Sobreika TT, Souza MF, Melo $L L$, Silveira ER. Investigation on the gastroprotective and antidiarrheal properties of ternatin,a tetramethoxyflavone from Egletes viscose. Planta Med, 1997; 63: 1496-1497.

31. Sanchez de Medina F, Galvez J, Gonzalez M, Zarzuelo A, Barrett KE. Effects of quercetin on epithelial chloride secretion. Life Sci, 1997; 61: 2049-2055.

32. Su $Y L$, Leung $L K$, Bi YR, Huang $Y$, Chen $Z Y$. Antioxidant activity of flavonoids isolated from Scutellaria rehderiana. J Am Chem Soc, 2000; 77: 807-812.

33. Mora A, Paya M, Rios JL, Alcaraz MJ. Structure activity relationships of polymethoxy flavones and other flavonoids as inhibitors of nonenzymic lipid peroxiation. Biochem Pharmacol, 1990; 36: 317-322. 